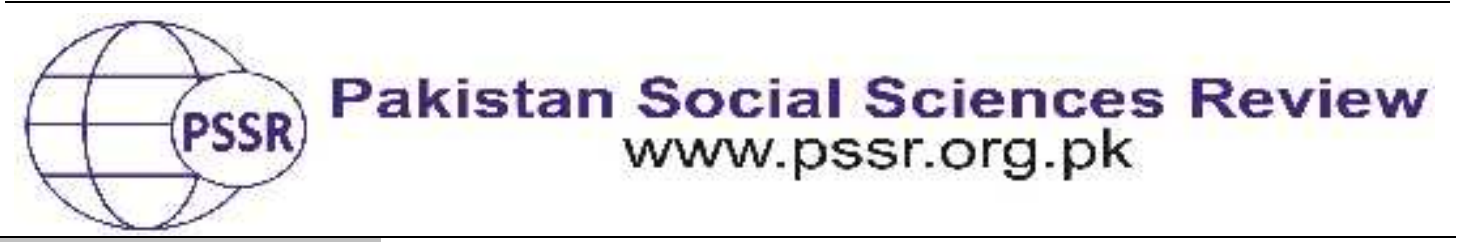

RESEARCH PAPER

\title{
People's Perception about Consanguineous Marriages and Child Health Issues: A Case Study in Gujranwala
}

Rizwana

Ph. D Scholar, Institute of Social and Cultural Studies (ISCS), University of the Punjab, Lahore, Punjab, Pakistan

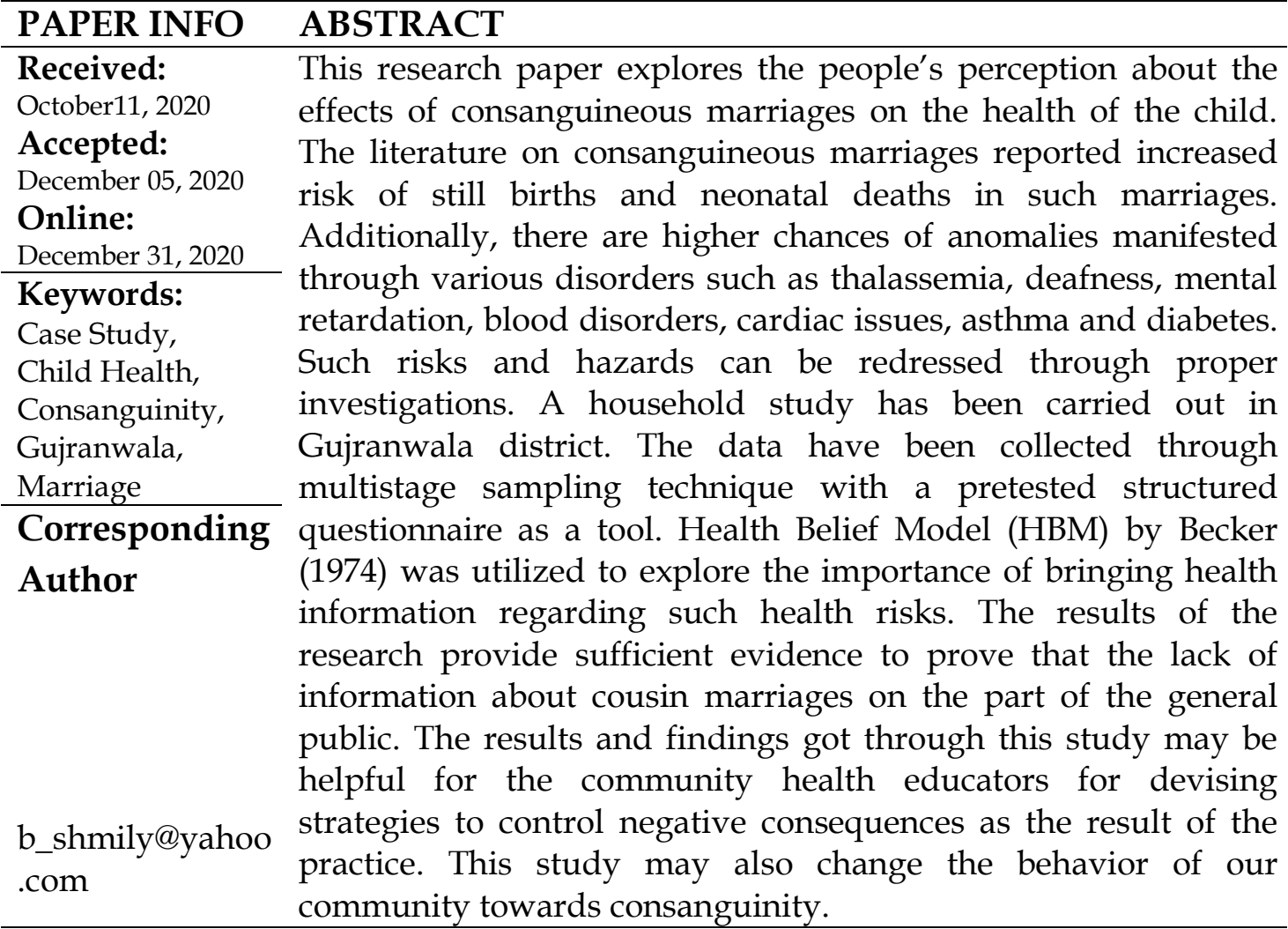

\section{Introduction}

Boys and girls, who are cousins, are united as husbands and wives all over the world. Such trends are most general in Arabian lands and in the subcontinent. Such wed locks are considered relatively safer and more durable than the other sort of unions. There are also many social and economic gains. In spite of all these benefits, there are still the risks attached with such marriages. There is lack of knowledge among people about the harmful effects of cousin marriage. There can be seen so many risks of cousin marriages which are not easy to control. Practical evidences show that such unions invite various sort of health complications for both mother and child. These health problems are very acute but because of various 
factors the intensity of such issues has not yet been explored and investigated. Every human being, male and female, has 46 chromosomes, organized into 23 sets. Of these, 22 sets are related to the diseases and only one pair determines sex. The genes are determined by chromosomes. Each pair of chromosome bears a single set of gene, so that everybody has two copies of each gene which are called alleles; one from male and other from female. For a healthy and normal child, both copies of human genes have to work normally (Bittles, 2010). There can be seen many health issues related to receding genes. Mostly, there are chances of abnormalities and hereditary disorders in children of consanguineous unions which are called autosomal recessive hereditary disorders (Fauzia \&Batool, 2018). These disorders may range from neural tube malfunctioning and sickle cell anemia to sudden heart failures.

If both the parents carry the same autosomal passive malady, the risks of the disability of the child is far much greater than a normal one. The marriages through consanguinity with genetic diseases like neural tube malfunctioning and cleft lip and/or sense of taste have been studied by Tadmouri (2009). Hereditary diseases such as childhood deafness and color blindness have been commonly traced in consanguineous marriages. (Al-Gazali. 1998). A study undertaken by Olusanya and Okolo (2006) shows that the kids as the result of cousin marriages in Nigeria have to face hearing issues.150 Jewish children were taken as samples with issues in audition in 139 couples who were near or first cousins; and even some of them were the first cousins. There was seen inherent blindness more than the rest of the lack in their physique and mind. (Stoll C, Alembik Y, Dott B, Roth MP.1992).

Hamamy (2011) revealed through several studies the issue of child mortality through miscarriages in consanguineous couples. These are evaluated to be around $2-3 \%$ higher than the normal deaths of the new born babies with non-cousin marriages. Madhavan \& Narayan (1991) find that the chances of mental retardation in the children are also high. Studies also point towards decline in children's cognitive capacities due to inbreeding and recurrence of mental limitation among siblings from cousin couples (Saad, 2014). M.A. Hashmi (1997) also tried to prove through case studies that the ratio of transformations of hereditary diseases in children of cousin couples is $40 \%$ as compared to non-cousin couples which is $26 \%$. Such hereditary disorders include myocardial infection, arteriosclerosis, cancer, mental retardation, diabetes, weight loss, hypertension, schizophrenia, asthma and cancer.

A community-based study was finalized by Joseph (2015) to evaluate the mindfulness of individuals regarding impacts of cousin couples keeping in view the different socio-demographic factors and complications among children. Bittles (1994), Bittles, (2012), Bennett, (2002), and Bittles and Black, (2010 try to establish a strong link of consanguineous marriages with the high risks of depression, hereditary malformations, high level of infant mortality and lethargic outcomes. A 
research by Stoltenberg (1997), discovers the relation between parental consanguinity and inborn disorders in Norway.

Rudan (2003) and Wright, (2003) discover peptic ulcer, gout, adult type diabetes, asthma, uni/bipolar depression, epilepsy, schizophrenia, cancer, stroke and coronary heart disease which usually catch to the cousin couples. Mansour (2009) finds genuine brain disorder causing violent temperament and behavior. Rao (2009) and Bener (2017) point out many other common mental diseases which are related to cousin marriages. These may be depression, anxiety and violent behaviors. Zakar et al (2014) studies the causes of unfavorable birth results by utilizing two independent variables, neonatal death and small-size birth. The results reveal that first-degree affiliation was essentially related with the hazard of small-size birth (OR $1.14 ; 95 \%$ CI, 1.01-1.29) and neonatal passing (OR 1.51; 95\% CI, 1.16-1.95). Stolenberg (1998) and Sure'n \& Grjibovski (2007) in a Norwegian based study highlight a number of first-cousin marriages through the variable of age of the couple. Autosomal passive retinitis pigments is reported to occur more commonly in populaces where consanguineous unions are preferred (Naz, 2010; Iqbal, 2011). In a research in Kuwait, blindness was found not only amongst the consanguineous families but also among non-consanguineous ones (Al-Kandari YY, Crews DE. 2011) although a study in Saudi Arabia gave the contrary results(Tabbara, 1985).

The above given studies prove that consanguineous marriages result in physical, psychological and mental diseases and disorders. These marriages, settled under different norms, customs, beliefs and myths prove to be the potential threats to the expected babies. Such threats and abnormal cases are mostly seen in the developing countries in general; and Pakistan, being a developing state, needs rigorous studies in particular. However most of these studies are based on clinical information and secondary data; hence lack socio-cultural dimension of this issue. There is a dire need to study and survey the causes and effects of consanguinity on the health of the newborn kids particularly in the region/ district Gujranwala.

\section{Theoretical Framework}

The Health Belief Model (HBM) has been used as the theoretical framework for the present research. It was initially introduced by Becker (1974) to clarify utilization of wellbeing administrations and has been broadly connected to other health-related practices also. This model links belief with effects on health of the parents and kids. This may contribute in developing and encouraging understanding of the potential relationship between hereditary hazards and consanguineous marriages. Following is the diagrammatical description of HBM as: 


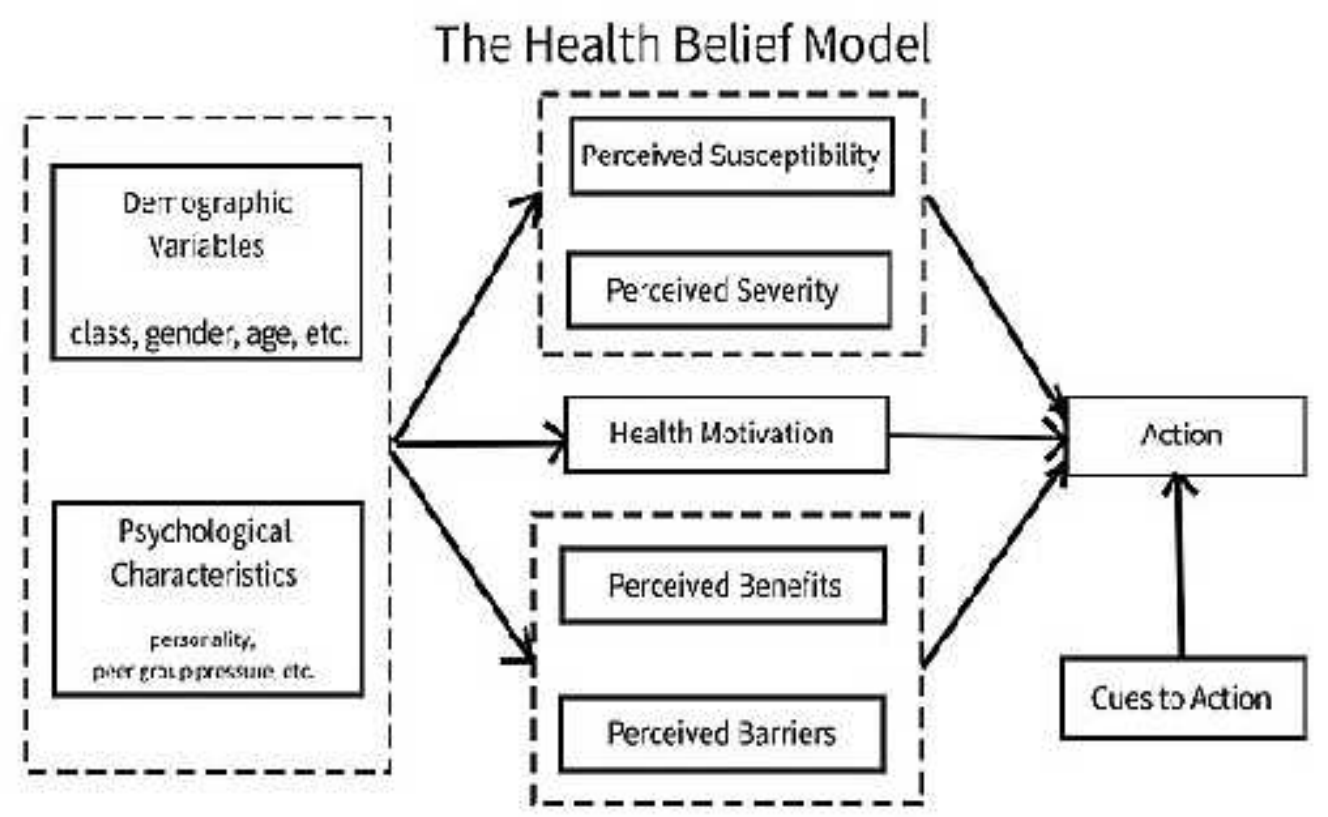

The practices of consanguineous marriages in Gujranwala district have been studied with the application of HBM and with special focus on the health of the newly born children to consanguineous couples.

\section{Material and Methods}

This is purely a theoretical research with the application of Health Belief Model (HBM) which is provides a clear theoretical demonstration and endeavors to clarify and anticipate wellbeing behaviors by centering on the behaviors and convictions of people.For the current study, the researcher has used Taro Yamani (1967) formula to encompass the one million population (in the year 2013) of the district. The test is computed by putting the values within the equation: $n=N / 1+N e^{2}$. Here ' $n$ ' is sample size (sample collected was 400) required, ' $N$ ' is Number of persons in the populace and ' $\mathrm{e}$ ' stands for Allowed error (\%). Data have been collected through pre-tested multi-staged interview from the required number of subjects. The researcher probed all the queries to get responses from the participants of the research. Before entering into field,there was conducted pre-testin order to find and resolve the implicit issues

The data were collected through multi-staged interview in order to explore both positive and negative impacts. On the positive side, there are the socioeconomic benefits of cousin marriages. A qualitative analysis has been done to find the responses to the required investigations. To find out the relation between consanguineous marriages and the health outcomes of the kids p-values as $(0.00<0.05)$ have been applied. 


\section{Results and Discussion}

There have been given the results through four tables. Each table has been discussed in the light Health Belief Model, particularly pertaining to child health issues.

Table 1

Socio-demographics of the Respondents

\begin{tabular}{ccccc}
\hline \multirow{2}{*}{ Variables of the Respondents } & Frequency & Percent & $\begin{array}{c}\text { Cumulative } \\
\text { Percent }\end{array}$ \\
\hline Age & Rural & 400 & 100.0 & 100.0 \\
\hline & $15-24$ & 136 & 34.0 & 34.0 \\
\cline { 2 - 5 } & $25-34$ & 72 & 18.0 & 52.0 \\
\cline { 2 - 5 } Education of respondent & $35-44$ & 104 & 26.0 & 78.0 \\
\cline { 2 - 5 } & More than 44 & 88 & 22.0 & 100.0 \\
\cline { 2 - 5 } & Total & 400 & 100.0 & \\
\hline \multirow{3}{*}{$\begin{array}{c}\text { Occupation of the } \\
\text { Respondents }\end{array}$} & Business & 4 & 1.0 & 1.0 \\
\cline { 2 - 5 } & Govt. JOB & 32 & 8.0 & 9.0 \\
\cline { 2 - 5 } & Private Job & 28 & 7.0 & 16.0 \\
\cline { 2 - 5 } & Housewife & 336 & 84.0 & 100.0 \\
\cline { 2 - 5 } & Total & 400 & 100.0 & \\
\cline { 2 - 5 } & Married & 356 & 89.0 & 89.0 \\
\hline \multirow{2}{*}{ Marital Status } & Separated/ & 28 & 7.0 & 96.0 \\
\cline { 2 - 5 } & Divorced & 16 & 4.0 & 100.0 \\
\cline { 2 - 5 } & Widow & 400 & 100.0 & \\
\cline { 2 - 5 } & Total & &
\end{tabular}

The data, given above, show the socio-demographic features of cousin marriages and the child health hazards. The above shows age intervals of the participants. The participants of this research have been divided into four categories. It is clear from the above data that most of the people are in the range of 15-24 age and that is about 34 percent.

The category of 25-34 in age has the fewest number of participants. The education level of the respondents is the main marker of the research as it tells the level of the perception of the issue in the true sense of the word. The table given above explains that most of the respondents are illiterate. They form the primary category and constitute $35 \%$ and $28 \%$ of the total participants consecutively. It means that mostly the uneducated and less educated people prefer to have cousin marriages. The above given table also proves that 20 out of the total sample are the highly educated ones.

The above given table shows the occupation of the respondents of the study. It is clear that most of the ladies as mothers are domestic ones. In other words, they are not job doing ladies. The 336 women are the ladies staying at homes and have 
least social exposures. $1.0 \%$ are the ones who run a business while $8.0 \%$ are from the public sector.

The following table (as Table 2) shows the difference between the child health of consanguineously married and un-consanguineously married couples.

Table 2

Education VS Knowledge

\begin{tabular}{|c|c|c|c|c|c|c|c|c|}
\hline \multirow{2}{*}{$\begin{array}{l}\text { Sr. } \\
\text { No. }\end{array}$} & \multicolumn{2}{|c|}{$\begin{array}{l}\text { Knowledge About } \\
\text { Consanguineous }\end{array}$} & \multicolumn{5}{|c|}{ Education of Respondent } & \multirow{2}{*}{ \%age } \\
\hline & Marriage & & Uneducated & Primary & Middle & Secondary & Higher & \\
\hline \multirow{2}{*}{1} & $\begin{array}{c}\text { Do you know } \\
\text { that } \\
\text { consanguineous }\end{array}$ & Yes & 4 & 8 & 40 & 60 & 20 & 33 \\
\hline & $\begin{array}{c}\text { associated with } \\
\text { health } \\
\text { problems? }\end{array}$ & No & 136 & 104 & 28 & 0 & 0 & 67 \\
\hline \multirow[b]{2}{*}{2} & $\begin{array}{l}\text { Do you know } \\
\text { that children of } \\
\text { consanguineous }\end{array}$ & Yes & 8 & 8 & 36 & 60 & 20 & 33 \\
\hline & $\begin{array}{c}\text { couples have } \\
\text { more chances of } \\
\text { having various } \\
\text { diseases? }\end{array}$ & No & 132 & 104 & 32 & 0 & 0 & 67 \\
\hline \multirow{2}{*}{3} & $\begin{array}{c}\text { Do you know } \\
\text { that the } \\
\text { children of } \\
\text { consanguineous }\end{array}$ & Yes & 0 & 4 & 36 & 52 & 0 & 23 \\
\hline & $\begin{array}{c}\text { couple have } \\
\text { greater chances } \\
\text { of genetic } \\
\text { problems? }\end{array}$ & No & 140 & 108 & 32 & 8 & 20 & 77 \\
\hline \multirow{2}{*}{4} & $\begin{array}{c}\text { Do you know } \\
\text { that the } \\
\text { children of }\end{array}$ & Yes & 0 & 4 & 32 & 60 & 4 & 25 \\
\hline & $\begin{array}{l}\text { couples have } \\
\text { greater chances } \\
\text { of birth defects? }\end{array}$ & No & 140 & 108 & 36 & 0 & 16 & 77 \\
\hline 5 & $\begin{array}{l}\text { Do you know } \\
\text { that } \\
\text { consanguinity } \\
\text { increases the }\end{array}$ & Yes & 4 & 4 & 32 & 52 & 4 & 24 \\
\hline
\end{tabular}




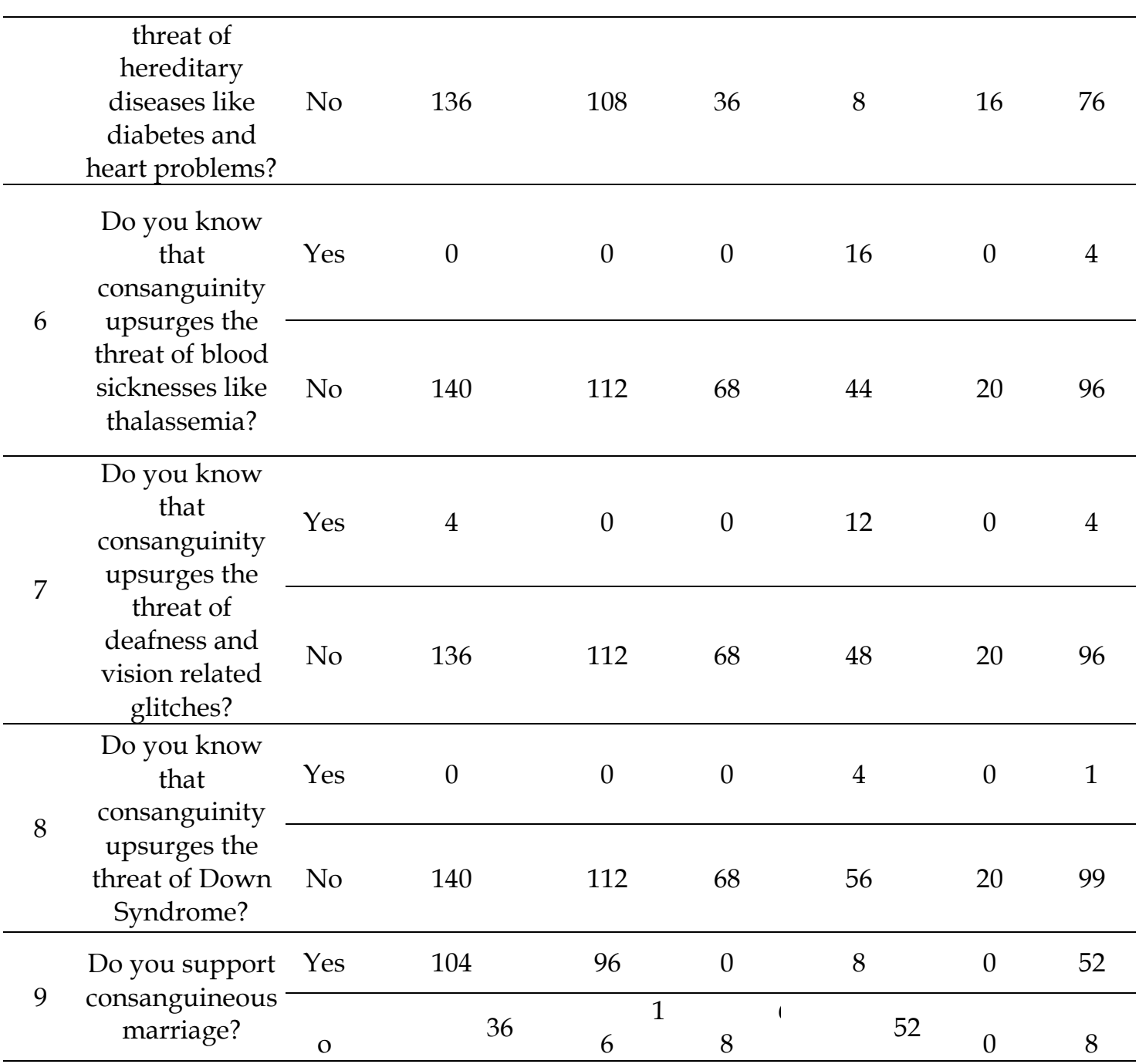

In the above given Table 2, total 9 questions were asked from 400 cousin couples. Every question had different percentage. In the question 1 the respondents were asked "Do you know that consanguineous marriage is associated with health problems?" Just 33\% were aware of the health problems about the health problems of consanguineous marriage. $67 \%$ people were not aware about the health problems of consanguineous marriage. Same as in the next questions they were asked about the different health issues about the children and the results given in the Table-2 in front of every question. The rate of low percentage of consanguineously married people was 1 and the higher percentage was 52. Same as the low percentage of nonconsanguineously married people was 48 and the higher was 99. Cousin marriages are not often related to side effects rather negative health results are considered as the "will of God". Existing literature proves that lack of knowledge invites such marriage in Pakistan as they don't have sufficient knowledge about cousin marriage. Cousin weddings are connected with ailment and illness of the newly born children. Still births and infant mortality can be seen as the two major issues in such cases. The impacts of relationship on newborn child passing appear to be the foremost reliable 
with consanguinity. This shows that there are many chances of abortions in the case of cousin marriages.

The followings table also establishes the relationship between cousin marriage and sudden and early deaths of the new-born ones.

Table 3

Ever Given birth to a Child who was Born and Died Later

\begin{tabular}{|c|c|c|c|c|c|}
\hline & \multicolumn{4}{|c|}{ How many children died after birth? } & \multirow[b]{2}{*}{ Total } \\
\hline & 0 & one & two & $\begin{array}{l}\text { more } \\
\text { than } \\
\text { two }\end{array}$ & \\
\hline Non Consanguinity & 104 & 8 & 0 & 0 & 112 \\
\hline Consanguinity & 112 & 120 & 52 & 4 & 288 \\
\hline Total & 216 & 128 & 52 & 4 & 400 \\
\hline
\end{tabular}

The above given tabulation No. 3proves that 176 out 400 couples who had cousin relationships and gave birth to alive children but later on they died shortly. The table given above presents that total 288 out of 400 respondents stated that they were cousins or near relatives and 184 gave births to single babies resulting in their early deaths. These data prove a strong relationship between such marriages and health hazards to the children.

\section{Still Birth}

The given table 4again shows the link between cousin marriages and the children who died suddenly after births. This also proves that there are greater chances of early deaths of the kids in such couples.

In the case of non-cousin marriages, the death rate was 4 out of 112, while in the case of cousin marriages, the death rate is far much higher as 84 out of 288 . Similarly, two children died after birth is 0 for non-consanguinity and 52 for consanguineous marriage. Similarly, Non-consanguinity has miscarriages as 4out of 112 children while in the case of consanguinity, there are miscarriages as 84 out of 288. So, the data show the relationship between mortality of the children and cousin marriages through the cross tabulation.

\section{Conclusion}

The present research is based on Health Belief Model (HBM) and assesses the issue of child health outcomes in the case of cousin couple consanguineous marriage.

This model is based on different stages of knowing and evaluating health behavior. The conclusions of the research and the levels are given for discussion. Perceived risk is the first level which states how individuals take the possible threats 
of any health outcome. This indicates the level of knowledge people have regarding threats of negative health outcome.

Table 4

Miscarriages and Still Births

\begin{tabular}{clccccc}
\hline & \multicolumn{4}{c}{ How many pregnancies ended in miscarriage } & \multirow{2}{*}{ Total } \\
\cline { 2 - 5 } & 0 & 1 & 2 & 3 & \\
\hline Non Consanguinity & 108 & 4 & 0 & 0 & 112 \\
\hline Consanguinity & 176 & 84 & 24 & 4 & 288 \\
\hline Total & 284 & 88 & 24 & 4 & 400 \\
\hline
\end{tabular}

The findings of the current study show that people don't have the sufficient knowledge about the health hazards attached with these marriages. Perceived severity is the reality of the illness and its results as seen by the person. Perceived benefits could be a person's own choice in diminishing the hazard of creating of illness. This shows using proper measures to control any sickness and in the context of the present research this implies the practices regarding consanguineous marriage. The conclusions of the present research prove that people lack proper practices to control such tendencies and practices in marriage issues. Decisions in the case of marriages are not properly taken. So far as the HBM is concerned, this factor restricts the apparent benefits for health seeking behavior. Perceived barriers to activity can be seen from the negative sides of health-oriented activities or which serve as boundaries that stir clashing motivations to maintain a strategic distance from activity. Endogamy and religious orientations play very important roles in serving the purpose of health outcomes with regard to cousin marriages. The most common diseases that are transferred to children can be seen ranging from physical handicapped to mental disorders. The infants can be seen as the primary victims to hereditary diseases because they have to face the direct impacts of the marriages among their parents as being cousin ones. Seminars, personal sessions of awareness, inclusion of some chapters related to such issues in the course outline of (post)graduate studies, sermons by religious scholars on pulpits and Premarital Screening (PMS) are strongly recommended so that such cases may either be avoided or at least minimized to the manageable limit. 


\section{References}

Al-Kandari, Y. Y. \& Crews, DE. (2011). The effect of consanguinity on congenital disabilities in the Kuwaiti population. J Biosoc Sci; 43: 65-73.

Bennett, R. Motulsky, AG. Bittles, AH, Hudgins, L. Uhrich, S. Lochner, Doyle D. Silvey, K. Scott, RC. Cheng, E. McGillivray, B. Steiner, RD. \& Olson, D. (2002). Genetic counseling and screening of consanguineous couples and their offspring: Recommendations of the National Society of Genetic Counselors. J Genet Counse111:97-119.

Bener, A. (2017). Does consanguinity increase the risk of mental illnesses? A population based study. European Psychiatry, 41, S512.

Bittles, A.H. \& Black, M.L. (2010a). Evolution in health and medicine Sackler colloquium: consanguinity, human evolution, and complex diseases. Proc NatlAcad Sci U S A 107(Suppl 1): 1779-1786

Bittles, A.H. \& Black, ML. (2010b). The impact of consanguinity on neonatal and infant health. Early Hum Dev 86:737-741

Bittles, AH. (2012). Consanguinity in Context. Cambridge University Press, Cambridge.

Bittles, AH. Black, ML. (2010). Consanguinity, human evolution and complex diseases. Proc Natl Acad Sci USA;107(1):1779-1786.

Bittles, AH. \& Neel, J.V. (1994). The costs of human inbreeding and their implications for variation at the DNA level. Nature Genetics 8, 117-121.

Hamamy, H. Antonarakis, S.E. Cavalli-Sforza L.L. Temtamy S. Romeo G. Ten Kate L.P. \& Bennett R.L. (2011). Consanguineous marriages, pearls and perils: Geneva International Consanguinity Workshop report. Genet Med 13:841-847

Hashmi, MA. (1997). Frequency of consanguinity and its effect on congenital malformation. A hospital bared study. JPMA 47: 751997.

Iqbal, M. Naeem, M. A. \& Riazuddin, S. A. (2011). Association of pathogenic mutations in TULP1 with retinitis pigmentosa in consanguineous Pakistani families. Arch Ophthalmol; 129: 1351-7.

Jaber L. Halpern G.J. \& Shohat (1998). The impact of consanguinity worldwide. Community Genet; 1:12-17.

Madhavan, T. Narayan, J. (1991). Consanguinity and mental retardation. Journal of Intellectual Disability Research, 35(2), 133-139. 
Mansour, H. Klei, L. Wood, J. Talkowski, M. Chowdari, K. Fathi, W. \& Nimgaonkar, V. L. (2009). Consanguinity Associated With Increased Risk for Bipolar I Disorder in Egypt. American Journal of Medical Genetics 150B(6), 879-885. http:// doi.org/10.1002/ajmg.b.30913

Naz, S. Riazuddin, S. A. Li, L. Shahid, M. Kousar, S. Sieving, P. A. Hejtmancik, J. F. \& Riazuddin, S. (2010). A Novel Locus for Autosomal Recessive Retinitis Pigmentosa in a Consanguineous Pakistani Family Maps to Chromosome 2p. American journal of ophthalmology, 149(5), 861-866. https://doi.org/10.1016/j.ajo.2009.12.034

Olusanya, B.O. \& Okolo, A.A. (2006). Adverse perinatal conditions in hearingimpaired children in a developing country. Paediatr Perinat Epidemiol; 20: 366-71.

Rao, T. S. S. Prabhakar, A. K. Jagannatha Rao, K. S. Sambamurthy, K. Asha, M. R. Ram, D. \& Nanda, A. (2009). Relationship between consanguinity and depression in a south Indian population. Indian Journal of Psychiatry, 51(1), 50-52. http:// doi.org/10.4103/0019-5545.44906

Rudan, I. Rudan, D. Campbell, H. Carothers, \& Wright, A. (2003a). Inbreeding and Risk of Late Onset Complex Disease. Journal of Medical Genetics, Vol. 40, pp. 925932

Rudan, I. Smolej-Narancic, N. Campbell, H. Carothers, A. \& Wright, A. (2003b). Inbreeding and the Genetic Complexity of Human Hypertension. Genetics, Vol. 163, pp. 1011-1021

Saad, H. A. Elbedour, S. Hallaq, E. Merrick, J. \& Tenenbaum, A. (2014). Consanguineous Marriage and Intellectual and Developmental Disabilities among Arab Bedouins Children of the Negev Region in Southern Israel: A Pilot Study. Frontiers in Public Health, 2, 3. http:/ / doi.org/10.3389/fpubh.2014.00003

Suren, P. Grjibovski, A. \& Stoltenberg, C. (2007). Consanguineous marriage in Norway; prevalence and medical consequences; Report; Oslo: Nasjonalt folkehelseinstitutt; 2:1-64.

Stoll, C. Alembik, Y. Dott, B. \& Roth, MP. (1992). Epidemiology of congenital eye malformations in 131,760 consecutive births. Ophthalmic Paediatr Genet; 13: 17986.

Stoltenberg, C. (1998). Birth defects, stillbirth and infant death; Epidemiological studies of the effects of consanguinity and parental education. Births in Norway 1967-1995. Thesis: Faculty of Medicine. The University of Oslo. NorJ Epidemiol; 8 (Suppl 2):1-120. 
Tabbara, KF. \& Badr, IA. (1985). Changing pattern of childhood blindness in Saudi Arabia; Br J Ophthalmol; 69: 312-5.

Tadmouri, G.O. Nair, P. Obeid, T. Al Ali, M.T. Al Khaja, N. \& Hamamy, H.A. (2009). Consanguinity and reproductive health among Arabs. Reprot Health 6:17.

Yamane, Taro. (1967). Statistics: An Introductory Analysis; 2nd Edition, and New York: Harper and Row.

Zakar, R. Zakar, M. Aqil, N. \& Naruallah, M. (2015). Paternal factors associated with neonatal mortality and births with low weight: evidence from Pakistan Demographic and Health Survey 2006-07. Maternal and Child Health Journal.DOI: 10.1007/s10995-015-1674-5 